12. Shawver, L. K., Slamon, D. and Ullrich, A., Smart drugs: tyrosine kinase inhibitors in cancer therapy. Cancer Cell, 2002, 1(2), 117123 .

13. Leung, K. W. and Wong, A. S., Pharmacology of ginsenosides: a literature review. Chin. Med., 2010, 5(1), 20.

14. Shin, H. R., Kim, J. Y., Yun, T. K., Morgan, G. and Vainio, H., The cancer-preventive potential of Panax ginseng: a review of human and experimental evidence. Cancer Causes Control, 2000, 11(6), 565-576.

15. Park, J. D., Rhee, D. K. and Lee, Y. H., Biological activities and chemistry of saponins from Panax ginseng CA Meyer. Phytochem. Rev., 2005, 4(2-3), 159-175.

16. Kim, B. J., Involvement of melastatin type transient receptor potential 7 channels in ginsenoside $\mathrm{Rd}$-induced apoptosis in gastric and breast cancer cells. J. Ginseng Res., 2013, 37(2), 201.

17. Tawab, M. A., Bahr, U., Karas, M., Wurglics, M. and SchubertZsilavecz, M., Degradation of ginsenosides in humans after oral administration. Drug Metab. Dispos., 2003, 31(8), 10651071

18. Jeong, A., Lee, H.-J., Jeong, S.-J., Lee, H.-J., Lee, E.-O., Bae, H. and Kim, S.-H., Compound $\mathrm{K}$ inhibits basic fibroblast growth factor-induced angiogenesis via regulation of p38 mitogen activated protein Kinaseand AKT in human umbilical vein endothelial cells. Biol. Pharm. Bull., 2010, 33(6), 945-950.

19. Lee, I. K. et al., Compound K, a metabolite of ginseng saponin, induces mitochondria-dependent and caspase-dependent apoptosis via the generation of reactive oxygen species in human colon cancer cells. Int. J. Mol. Sci., 2010, 11(12), 4916-4931.

20. Mathiyalagan, R., Subramaniyam, S., Kim, Y. J., Natarajan, S. Min, J. W., Kim, S. Y. and Yang, D. C., Synthesis and pharmacokinetic characterization of a $\mathrm{pH}$-sensitive polyethylene glycol ginsenoside CK (PEG-CK) conjugate. Biosci. Biotechnol. Biochem., 2014, 78(3), 466-468.

21. Benet, L. Z., Kroetz, D., Sheiner, L., Hardman, J. and Limbird, L., Pharmacokinetics: the dynamics of drug absorption, distribution, metabolism, and elimination. Goodman and Gilman's the Pharmacological Basis of Therapeutics, 1996, pp. 3-27.

22. Sathishkumar, N., Karpagam, V., Sathiyamoorthy, S., Woo, M. J., Kim, Y.-J. and Yang, D.-C., Computer-aided identification of EGFR tyrosine kinase inhibitors using ginsenosides from Panax ginseng. Comput. Biol. Med., 2013, 43(6), 786-797.

23. Poroikov, V. V. et al., PASS biological activity spectrum predictions in the enhanced open NCI database browser. J. Chem. Inf. Comput. Sci., 2003, 43(1), 228-236.

24. Trott, O. and Olson, A. J., AutoDock Vina: improving the speed and accuracy of docking with a new scoring function, efficient optimization, and multithreading. J. Comput. Chem., 2010, 31([Trott, 2010 \#35]), 455-461.

25. Pai, E. F., Krengel, U., Petsko, G. A., Goody, R. S., Kabsch, W. and Wittinghofer, A., Refined crystal structure of the triphosphate conformation of H-Ras $\mathrm{p} 21$ at 1.35 A resolution: implications for the mechanism of GTP hydrolysis. EMBO J., 1990, 9(8), 2351.

26. Ranga, R. S., Sowmyalakshmi, S., Burikhanov, R., Akbarsha, M. A. and Chendil, D., A herbal medicine for the treatment of lung cancer. Mol. Cell Biochem., 2005, 280(1-2), 125-133.

27. Aceituno, V. C., Ahn, S., Simu, S. Y., Wang, C., Mathiyalagan, R. and Yang, D. C., Silver nanoparticles from Dendropanax morbifera Léveille inhibit cell migration, induce apoptosis, and increase generation of reactive oxygen species in A549 lung cancer cells. In Vitro Cell. Develop. Biol.-Anim., 2016, 1-8.

28. Liu, N., Li, Y., Su, S., Wang, N., Wang, H. and Li, J., Inhibition of cell migration by ouabain in the A549 human lung cancer cell line. Oncol. Lett., 2013, 6(2), 475-479.

29. Collins, T. J., ImageJ for microscopy. BioTechniques, 2007, 43(1 Suppl), 25-30.
30. Siddiqi, M. H., Siddiqi, M. Z., Ahn, S., Kim, Y.-J. and Yang, D. C., Ginsenoside Rh1 induces mouse osteoblast growth and differentiation through the bone morphogenetic protein 2/runt-related gene 2 signalling pathway. J. Pharm. Pharmacol., 2014, 66(12), 1763-1773.

31. Siraj, F. M., Natarajan, S., Huq, M. A., Kim, Y. J. and Yang, D. C., Structural investigation of ginsenoside $\operatorname{Rf}$ with $\operatorname{PPAR} \gamma$ major transcriptional factor of adipogenesis and its impact on adipocyte. J. Ginseng Res., 2014.

32. Choi, K.-T., Botanical characteristics, pharmacological effects and medicinal components of Korean Panax ginseng CA Meyer. Acta Pharmacol. Sin, 2008, 29(9), 1109.

33. Hwang, J. W. et al., Mountain ginseng extract exhibits anti-lung cancer activity by inhibiting the nuclear translocation of NF- $\kappa \mathrm{B}$. Am. J. Chin. Med., 2012, 40(01), 187-202.

ACKNOWLEDGEMENTS. This work was supported by the Korea Institute of Planning and Evaluation for Technology in Food, Agriculture, Forestry and Fisheries, Republic of Korea (313038-03-2-SB010).

Received 15 July 2015; revised accepted 19 April 2016

doi: $10.18520 / \mathrm{cs} / \mathrm{v} 111 / \mathrm{i} 6 / 1071-1077$

\section{Microbial water desalination and bio-electricity generation - role of biomass carbon}

\author{
A. Carmalin Sophia* and V. M. Bhalambaal \\ National Environmental Engineering Research Institute, CSIR, \\ Taramani, Chennai 600 113, India
}

Microbial desalination cells (MDCs) are modified microbial fuel cells (MFC) that are energy-sustainable. They use organic matter in wastewater as the energy source for desalination. The electric potential gradient is caused by exoelectrogenic bacteria. A typical MDC has a middle compartment for water desalination between the anode and cathode chambers. Our study reports lab-scale desalination, for evaluating the role of carbon from biomass waste, i.e. coconut shells. Control experiments were performed in the absence of activated carbon. Different initial salt concentrations (25 and $35 \mathrm{gl}^{-1}$ ) were investigated. MDC produced a maximum voltage of $460 \pm 13 \mathrm{mV}$ simultaneously removing about $83.3 \pm 1.3 \%$ of $\mathrm{Na}^{+}$and $57.8 \pm 1.1 \%$ of $\mathrm{Cl}^{-}$, in the desalination cycle. The control MDC produced a maximum of $260 \pm 8 \mathrm{mV}$ and $69.3 \pm 2 \%$ of $\mathrm{Na}^{+}$removal and $51 \pm 1.5 \% \mathrm{Cl}^{-}$removal. These results explain the role of using activated carbon for improved power production and water desalination.

*For correspondence. (e-mail: ac_sophia@neeri.res.in) 
The SEM image of the biofilm shows pili (nanowires) with rod-shaped microorganisms. EDAX confirmed the presence of minerals such as $\mathrm{Al}, \mathrm{P}, \mathrm{K}, \mathrm{O}, \mathrm{N}$, which may be due to chemical scale formation (especially $P$, $\mathrm{Na}$ and $\mathrm{Ca})$.

Keywords: Biomass carbon, graphite electrodes, microbial desalination, microbial fuel cell, potable water.

CLEAN drinking water has become a major challenge for the world. The United Nations estimates that one third of the world's population is living in water-deficient regions ${ }^{1}$. Groundwater, rivers and lakes have provided water for domestic, agricultural and industrial purposes. However, urbanization and population growth have resulted in water pollution and hence shortage. Nevertheless, oceans are inexhaustible sources of water, but their main disadvantage is high salinity. It would be a breakthrough if the portable water-scarcity problem is tackled by desalinating this water. Desalination technologies convert saline water to clean water, however, the present technologies such as reverse osmosis are energy-intensive involving high capital $\operatorname{cost}^{2-4}$.

Microbial desalination cell (MDC) is an emerging concept for water desalination and has gained increasing attention these days ${ }^{5-12}$. MDC is a modified microbial fuel cell (MFC) made up three compartments. Saline water is fed into the middle compartment, separated from the anode chamber by an anion exchange membrane (AEM), and from the cathode chamber by a cation exchange membrane $(\mathrm{CEM})^{5}$. The anode chamber is anaerobic and is filled with a medium that can support anerobic electrochemically-active microbial growth. These microorganisms grow on the surface of anode forming a biofilm, oxidize organic substrates and release electrons $\left(\mathrm{e}^{-}\right)$, which move to the cathode to reduce terminal electron acceptors (e.g. oxygen). To maintain electroneutrality, cations in the saline solution migrate through CEM into the cathode chamber and anions move through AEM into the anode chamber. Saline water in the middle chamber is thus desalinated. Cao et $a l^{5}$ successfully demonstrated the MDC concept. Charge balance issues associated with separation of anode and cathode in bioelectrochemical systems (BES) were investigated by Harnisch et al. ${ }^{13}$. MDC technology is being improved towards practical application $^{14}$. For example, configuration of MDCs has been designed as stacked or tubular for continuous opera$\operatorname{tion}^{15,16}$. Recently, ion-exchange resins were added to the salt chamber of an MDC to enhance desalination of brackish water with low salinity ${ }^{16-18}$.

In an effort to improve desalination efficacy and to lower the cost, we examined the role of biomass-based carbon in MDC. Performance of the MDC was evaluated in terms of changes in voltage and $\mathrm{NaCl}$ concentrations.

MDC was set up as reported by Cao et al. ${ }^{5}$. The volumes of the anode, middle desalination and cathode chamber were 500, 250 and $500 \mathrm{ml}$ respectively. The anode chamber was filled with the medium, reported ${ }^{5}$ to be spiked with domestic wastewater collected from the inlet of a treatment facility in Chennai, India. The $\mathrm{pH}$ and conductivity of the wastewater were $6.7 \pm 0.2$ and $6.1 \pm$ $0.6 \mathrm{mS} \mathrm{cm}{ }^{-1}$. Total initial COD was $480 \pm 50 \mathrm{~m} \mathrm{gl}^{-1}$. The anode chamber was filled with $5 \mathrm{~g}$ of activated carbon from biomass. After pretreatment, Neospeta (AHA, Japan) and Nafion 117 (Sigma-Aldrich) were used as AEM and CEM respectively. Graphite rods of area $17 \mathrm{~cm}^{2}$ were used as electrodes. Control experiments were performed without activated carbon to evaluate its significance. Different initial salt concentrations (25 and $35 \mathrm{gl}^{-1}$ ) were studied in the control and experimental MDC. The concentrations used for current desalination study represent the range of salinity found in sea water. The cell was connected to a $1000 \mathrm{~K} \Omega$ resistor. These experiments were run in triplicates under the same conditions for 25 days.

The activated coconut shell preparation and its characteristics had been explained earlier ${ }^{19}$. The $\mathrm{pH}$, moisture content and bulk density of the carbon were determined following APHA standard methods ${ }^{20}$. Sodium concentration was determined by a flame photometer (Systronics 128) whereas chloride concentration was determined by argentometric titration method ${ }^{20}$. COD was analysed by open reflux method ${ }^{20}$. Conductivity was measured using a conductivity probe (Eutech Instruments, India). $\mathrm{pH}$ was determined by a digital $\mathrm{pH}$ meter (Roy Instruments, India). Voltage ( $V$, volts) across the external resistor $\left(R_{\mathrm{ex}}=1000 \Omega\right)$ was recorded at definite intervals using a simple handheld digital multimeter (Mastech M3900). The current density (I, amps) through the electrical circuit was also measured. During the experiment, the solution in the anode was spiked with acetate solution when the voltage decreased to $<0.15 \mathrm{~V}$. BET surface area and the porosity determined by an ASAP 2010 automatic physical adsorber using purified nitrogen gas. The quantity of nitrogen adsorbed on carbon samples was used to

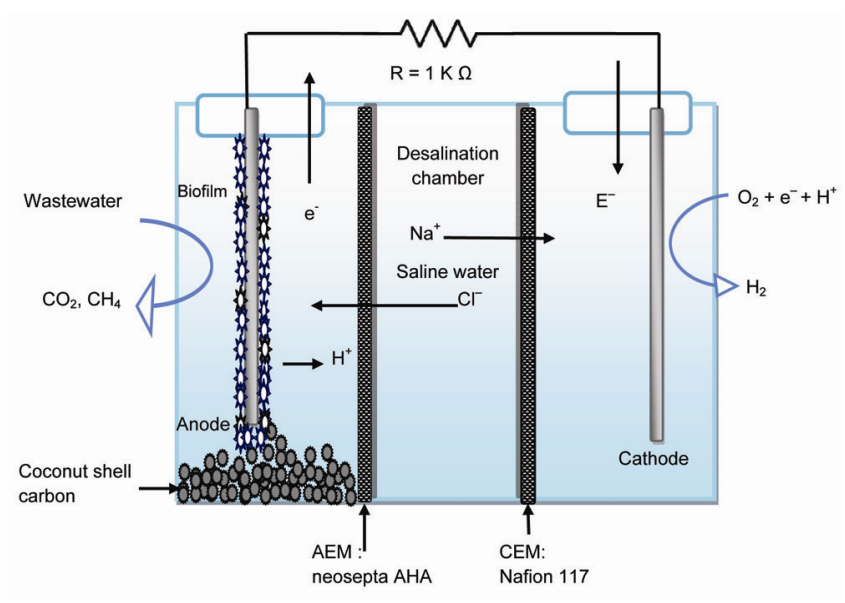

Figure 1. Schematic representation of MDC. 


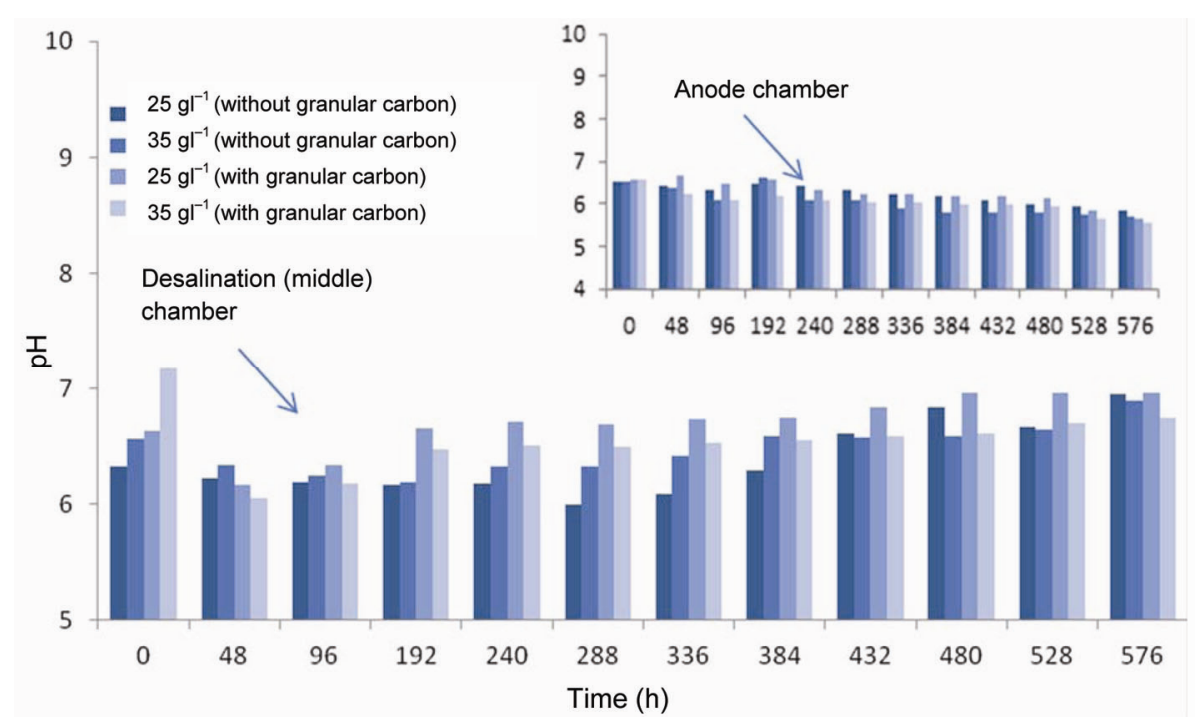

Figure 2. $\mathrm{pH}$ values recorded in the desalination chamber and the anode chamber (inset).

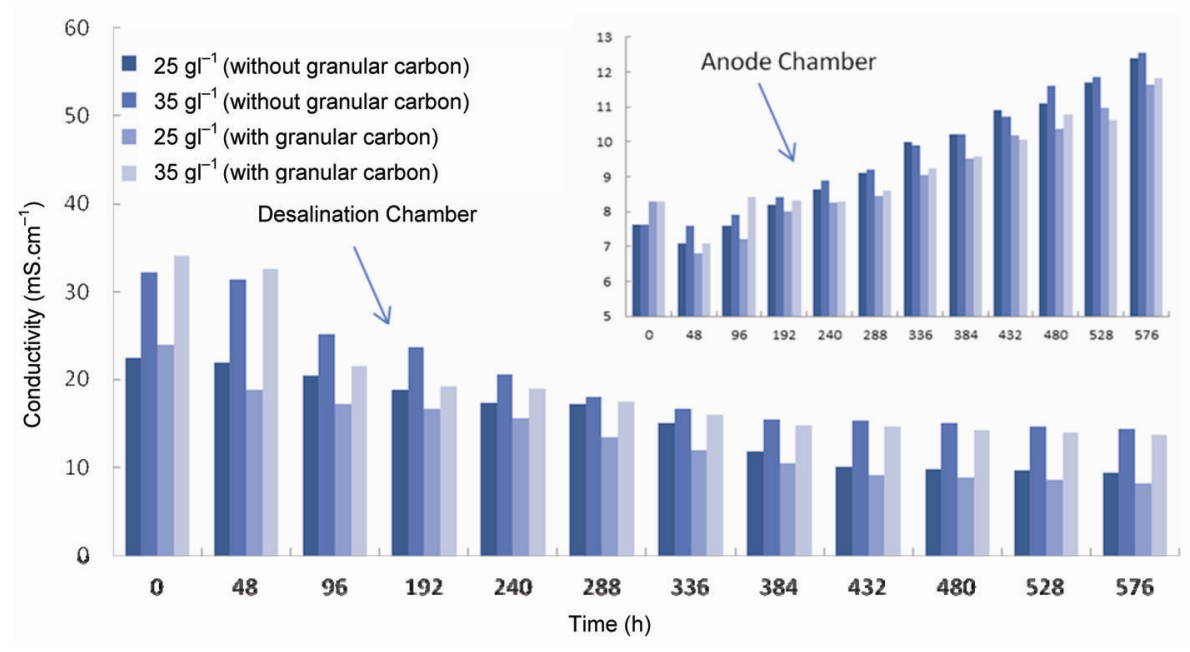

Figure 3. Conductivity readings recorded in the desalination chamber and the anode chamber (inset).

calculate the specific surface area. The surface morphology of the biofilm formed on the anode surface was recorded using Nova NanoSEM 450.

Our work is part of a long-term project aimed at exploring the role of different biomass carbons on the performance effieciency of MDC. The constructed MDC is represented in Figure 1.

The $\mathrm{pH}$ recorded in desalination chamber and anode chamber (Figure 2) shows marginal increase suggesting a possible migration of ions from the middle chamber to the anode chamber during desalination. The buffer capacity present in the wastewater probably helped maintain microbial activity while the buffering capacity of the MDC anode probably helped in maintaining the microbial population. Luo et al. ${ }^{21}$ examined the buffering capacity of MDC anolyte using $\mathrm{pH}$ and alkalinity measurements.

Figure 3 represents the variation in conductivity measured in the desalination and anode chambers. In the con- trol and experimental samples, the conductivity in desalination chamber substantially decreased and conductivity increased in the anode chamber. The conductivity in the middle chamber decreased about $55-58 \%$ in the control and $60-65 \%$ in the experimental MDC cycles. The gradual increase in conductivity of the anolyte solution during desalination may be attributed to the migration of chloride anions from the middle chamber salt solution to the anode chamber. The decrease in conductivity in desalination chamber during desalination in a MDC was reported earlier ${ }^{5,21,22}$.

Final COD of the anode anolyte after $576 \mathrm{~h}$ of operation was reduced by $22 \pm 3 \%\left(25 \mathrm{gl}^{-1}\right)$ and $21.2 \pm 2 \%$ $\left(35 \mathrm{gl}^{-1}\right)$ in the MDC control. Final COD in the experimental MDCs reduced by $38 \pm 3.5 \% \quad\left(25 \mathrm{gl}^{-1}\right)$ and $35.2 \pm 2.5 \%\left(35 \mathrm{gl}^{-1}\right)$. The reduction of COD in the MDC control may be due to microbial activity. The reason behind removal of COD in MDCs with granular coconut 
shell carbon may be apparently due to adsorption of organics onto the carbon and later microbial activity ${ }^{19}$. Bacterial growth on the carbon surface may remove/ consume the organics in wastewater and thus regenerate the carbon bed for further adsorption.

The voltage readings obtained during the four runs (Figure 4) and the current readings over a resistance of $1 \mathrm{~K} \Omega$ (Figure 5) show vacillation during the experimental runs, probably due to the complexity of the substrate, mixed consortium and microbial activities ${ }^{21}$. The anolyte was spiked with a known concentration of acetate when the voltage dipped close to $0.15 \mathrm{~V}$, to avoid substrate limitations for anode respiring bacteria. A maximum voltage of $460 \pm 13 \mathrm{mV}$ was obtained during the experimental MDC cycle run of $25 \mathrm{gl}^{-1} \mathrm{NaCl}$. For the same concentration of $\mathrm{NaCl}$, the control MDC cycle exhibited a maximum voltage of $260 \pm 8 \mathrm{mV}$. A maximum voltage of $425 \pm 9 \mathrm{mV}$ was obtained during the experimental MDC cycle run of $35 \mathrm{gl}^{-1} \mathrm{NaCl}$. For the same concentration of $\mathrm{NaCl}$, the control MDC cycle exhibited a maximum voltage of $226 \pm 5 \mathrm{mV}$. It was observed that desalination of lower salt concentrations $\left(25 \mathrm{gl}^{-1}\right)$ exhibited higher voltage than that of higher salt concentrations $\left(35 \mathrm{gl}^{-1}\right)$. The reasons may be (i) lesser growth of anode respiring bacteria; (ii) inhibition in biofilm formation due to the higher chloride concentration; or (iii) low $\mathrm{pH}$ within the anode biofilm ${ }^{22-24}$. The carbon surface may support a stronger bacterial community and increased electron transfer in the anodic chamber, through the formation of a biofilm.
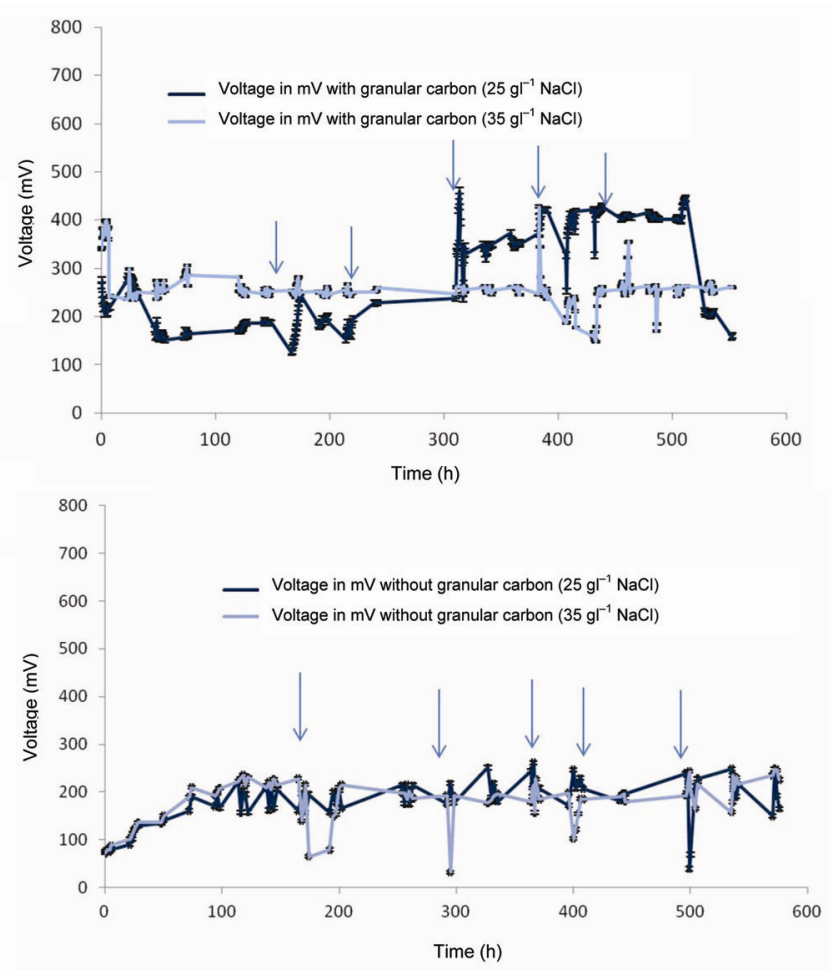

Figure 4. Voltage readings (arrows show spiking with acetate dose).
The current $(\mathrm{mA})$ readings (Figure 5) recorded maximum of 0.421 and $0.390 \mathrm{~mA}$ in the granular carbon loaded $\mathrm{MDC}$, for $25 \mathrm{gl}^{-1}$ and $35 \mathrm{gl}^{-1}$ of $\mathrm{NaCl}$ respectively. In the case of MDC without granular carbon, the maximum current readings recorded were 0.256 and $0.235 \mathrm{~mA}$ respectively.

The percentage desalination efficiency of the systems studied (Figure 6) shows that the saline water in the middle chamber was desalinated efficiently. The decrease in conductivity in the middle chamber is directly proportional to the percentage of $\mathrm{Na}$ and $\mathrm{Cl}$ removal. Sodium removal was found better in the experimental MDC than control. At $25 \mathrm{gl}^{-1}$ of $\mathrm{NaCl}, \mathrm{Na}^{+}$removal was higher in the experimental cycle than control $(83.3 \pm 1.3 \%>69.3 \pm 2 \%)$. Similarly for $35 \mathrm{gl}^{-1}$ of $\mathrm{NaCl}$, the experimental MDC run showed higher $\mathrm{Na}+$ removal than control $(78.5 \pm 1.6 \%>$ $61.4 \pm 1.2 \%$ ). The chloride removal also followed a similar trend. Removal of chloride was observed to be $57.8 \pm 1.1 \%$ and $51 \pm 1.5 \%$ in experimental MDC for $25 \mathrm{gl}^{-1}$ and $35 \mathrm{gl}^{-1} \mathrm{NaCl}$ respectively. There is a significant improvement in desalination when granular carbon is used. Salt removal efficiencies of up to $90 \%$ have been reported $^{25}$. However, much higher removal efficiencies are required to produce drinking water.

The SEM image of the anode surface after 25 days of biofilm growth (Figure 7), showed the formation of biofilm on surface of the graphite rod (anode) which had a scarce spread of exoelectrogenic bacteria. SEM studies had reported the formation of biofilm on the anode surface of bioelectrochemical systems fed with fermentable substrates like glucose ${ }^{26}$. Our study has micro-organisms
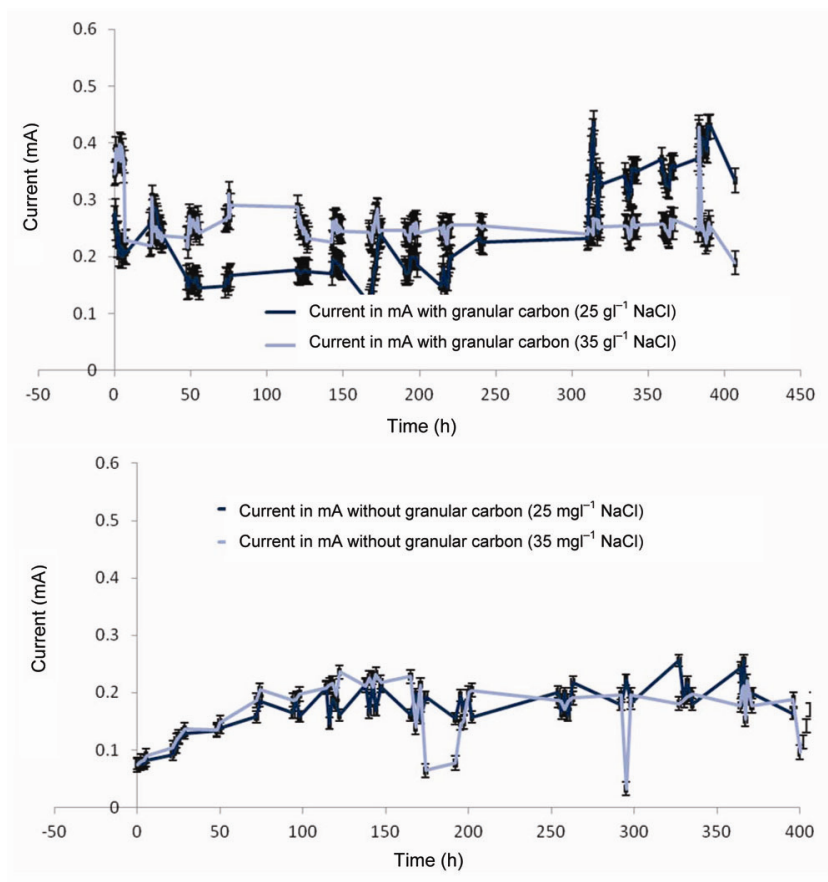

Figure 5. Current graphs.

CURRENT SCIENCE, VOL. 111, NO. 6, 25 SEPTEMBER 2016 

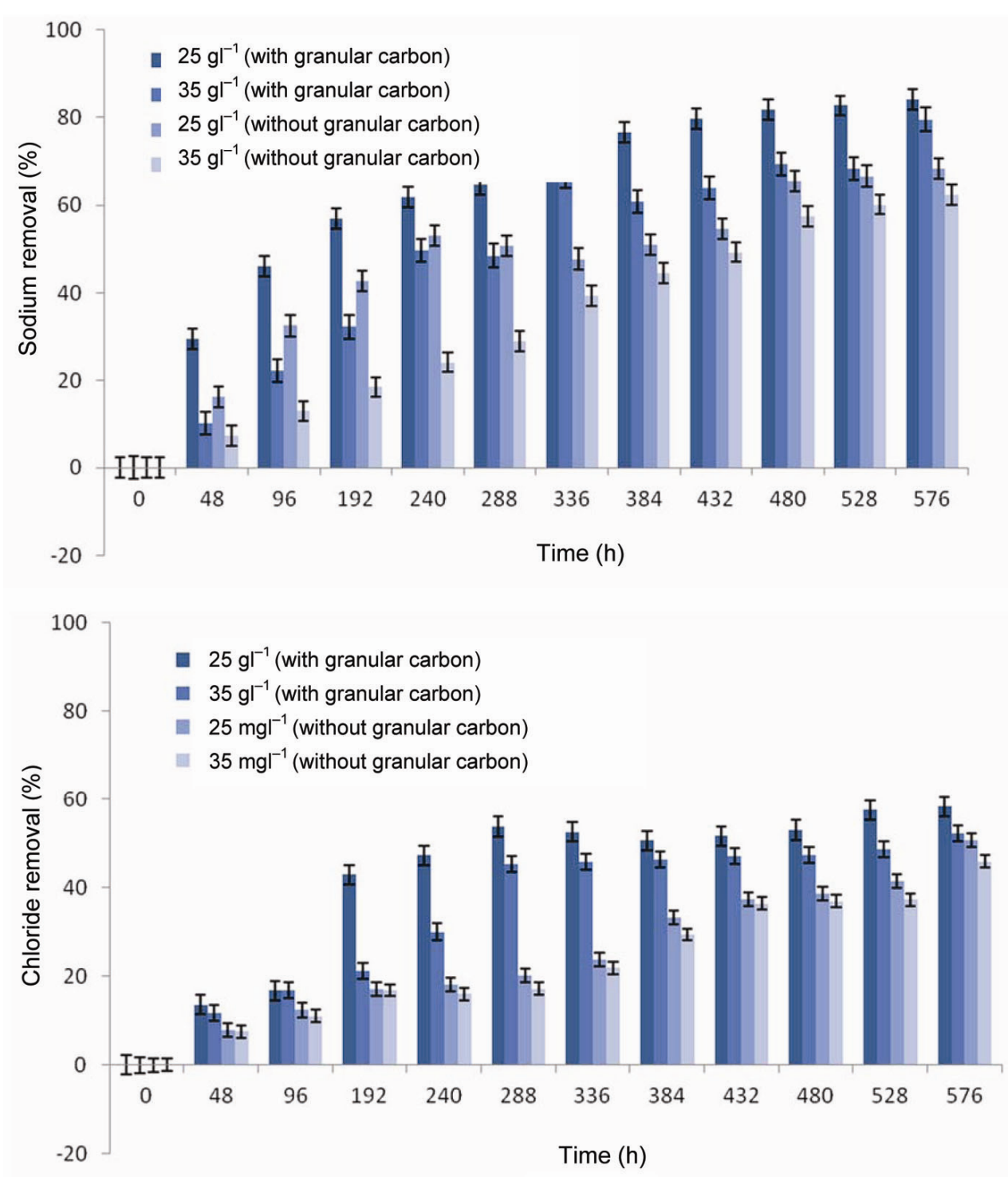

Figure 6. Removal percentage of sodium and chloride.
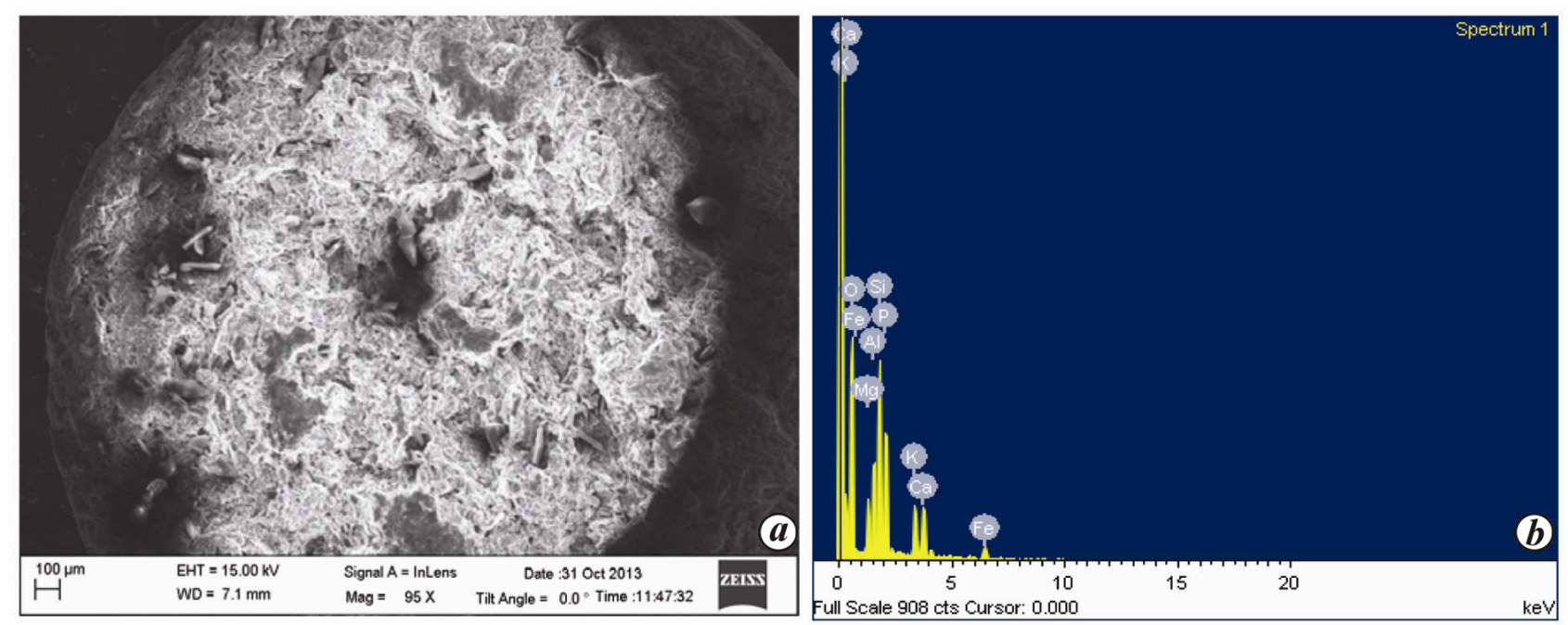

Figure 7. Biofilm on electrode; SEM and energy dispersive X-ray analysis (EDX). 
that uses acetate as food and shows a uniform molecule pili structure. Nanowires or pili may be the potential electron transfer pathways. However, this aspect needs to be confirmed and demonstrated. Kokabian and Gude ${ }^{27}$ have also reported similar uniform structures of biofilm. Electron $\left(\mathrm{e}^{-}\right)$transfer mechanisms in this system need to be investigated to deepen the understanding of the anode respiring bacteria. The uniform rod-like structures may even be dead cellular debris instead of live bacteria. EDX was taken on the dried section of anode biofilm to characterize the elements present (Figure $7 b$ ).

The presence of minerals such as $\mathrm{Al}, \mathrm{P}, \mathrm{K}, \mathrm{O}$, Na was observed, which may be due to chemical scale formation (especially $\mathrm{P}, \mathrm{Na}$ and $\mathrm{Ca}$ ).

Cost durability, life and performance of electrodes are significant in the design of microbial fuel cell (MFC) systems. Various kinds of electrode materials have been tried and developed in the past decade to improve MFC performance. There is a need to develop materials that possess better bacterial adhesion and perform electron transfer. Electrode design is a great challenge today to make the MFC a techno-economically scalable techno$\log y^{28}$. Recently, a variety of electrode materials have been extensively explored, viz. carbon paper, graphite rods, graphite plates or sheets, and carbon $\operatorname{cloth}^{29,30}$. Rabaey et $a l .{ }^{31}$ reported the use of granular graphite as an anode material in packed bed MFCs. Aelterman et al. ${ }^{32}$ compared graphite and carbon felt, and 2 and $5 \mathrm{~mm}$ graphite granules, and found that the graphite felt electrode yielded the highest maximum power output, amounting to $386 \mathrm{~W} / \mathrm{m}^{3}$. Coconut shell carbon used in this study has a large surface area (BET surface area $509 \mathrm{~m}^{2} \mathrm{~g}^{-1}$ ). The mesopore volume was found to be $0.05596 \mathrm{~cm}^{3} \mathrm{~g}^{-1}$ and micropore volume was $0.040807 \mathrm{~cm}^{3} \mathrm{~g}^{-1}$, hence is mesoporous. The open mesoporous structure of the coconut shell carbon might help in electrolyte transport. It can also support a strong electrode-biofilm interaction ${ }^{33}$. Coconut shell is a waste material and widely available biomass in India. Hence our study tries to explore the use of coconut shell carbon as electrode material. Further research is required in this area to understand the mechanism and role of this carbon in MFCs.

Our study is novel for desalination of water and power output in the presence and absence of activated carbon from biomass. The performance of MDC is better in terms of desalination and current production when the anode chamber is loaded with carbon from coconut shell. Further research in using different types of carbon from biomass sources may lead to a higher performance and techno-economically feasible designs for MFCs, that can be practically applied for salt removal and electricity generation.

Conflict of interest: The authors certify that there is no conflict of interest regarding the publication of this paper.
1. UN-Water Decade Programme on Capacity Development. Waterrelated migration, changing land use and human settlements, 5th World Water Forum: Topic 1.2, 2009.

2. Lattemann, S., Kennedy, M. D., Schippers, J. C. and Amy, G., Global desalination situation. In Sustainable Water for the Future: Water Recycling Versus Desalination (eds Escobar, I. C. and Schafer, A. I.), Elsevier, Amsterdam, 2010.

3. Shannon, M. A., Bohn, P. W., Elimelech, M., Georgiadis, J. G., Marinas, B. J. and Mayes, A. M., Science and technology for water purification in the coming decades. Nature, 2008, 452, 301310 .

4. Greenlee, L. F., Lawler, D. F., Freeman, B. D., Marrot, B. and Moulin, P., Reverse osmosis desalination: water sources, technology, and today's challenges. Water Res., 2009, 43, 23172348 .

5. Cao, X. X., Huang, P., Liang, K., Xiao, Y., Zhou Zhang, X. and Logan, B. E., A new method for water desalination using microbial desalination cells. Environ. Sci. Technol., 2009, 43, 71487152 .

6. Zhang, Bo. and He, Z., Improving water desalination by hydraulically coupling an osmotic microbial fuel cell with a microbial desalination cell. J. Membr. Sci., 2013, 441, 18-24.

7. Jacobson, K. S., Drew, D. M. and He, Z., Efficient salt removal in a continuously operated upflow microbial desalination cell with an air cathode. Bioresour. Technol., 2010, 102, 376-380.

8. Jacobson, K. S., Drew, D. M. and He, Z., Use of a liter-scale microbial desalination cell as a platform to study bioelectrochemical desalination with salt solution or artificial seawater. Environ. Sci. Technol., 2011, 45, 4652-4657.

9. Betts, K., Using microbes and wastewater to desalinate water. Environ. Sci. Technol., 2009, 43, 6895.

10. Ieropoulos, I., Greenman, J., Melhuish, C. and Hart, J., Comparative study of three types of microbial fuel cell. Enzyme Microbiol. Technol., 2005, 37, 238-245.

11. Logan, B. E., Hamelers, B., Rozendal, R., Schröder, U., Keller, J. and Freguia, S., Microbial fuel cells: methodology and technology. Environ. Sci. Technol., 2006, 40, 5181-5192.

12. Lovley, D. R., The microbe electric: conversion of organic matter to electricity. Curr. Opin. Biotechnol., 2008, 19, 564-571.

13. Harnisch, F., Schroder, U. and Scholz, F., The suitability of monopolar and bipolar ion exchange membranes as separators for biological fuel cells. Environ. Sci. Technol., 2008, 42, 17401746.

14. Rozendal, R. A., Hamelers, H. V. M., Rabaey, K., Keller, J. and Buisman, C. J. N., Towards practical implementation of bioelectrochemical wastewater treatment. Trends Biotechnol., 2008, 26(8), 450-459.

15. Rabaey, K., Clauwaert, P., Aelterman, P. and Verstraete, W., Tubular microbial fuelcells for efficient electricity generation. Environ. Sci. Technol., 2005, 39, 8077-8082.

16. Kuichang, Z., Jiaxiang, C., Shuai, L., Shijia, W., Changyong, Z., Peng, L. and Xia, H., A ten liter stacked microbial desalination cell packed with mixed ion-exchange resins for secondary effluent desalination. Environ. Sci. Technol., 2014, 48(16), 99179924.

17. Fang, Z., Man, C., Yan, Z., Raymond and Zeng, J., Microbial desalination cells with ion exchange resin packed to enhance desalination at low salt concentration. J. Membr. Sci., 2012, 417418, 28-33.

18. Alexandre, M., Kuichang, Z., Xue, X., Jincheng, W., Xi, L., Peng, L. and Xia, H., Microbial desalination cells packed with ionexchange resin to enhance water desalination rate. Bioresour. Technol., 2012, 118, 43-48.

19. Sophia, A. C., Catherine, D. and Bhalambaal, V. M., Utilization of rice-husk and coconut shell carbons for water disinfection. $J$. Environ. Sci. Eng., 2013, 55, 9-16. 
20. APHA, Standard Methods for the Examination of Water and Wastewater, American Public Health Association, American Water Works Association, Water Pollution Control Federation, Washington, DC, 2002, 22nd edn.

21. Haiping, L., Pei, X., Timberley, M., Roane, E., Jenkins, P. and Zhiyong, R., Microbial desalination cells for improved performance in wastewater treatment, electricity production and desalination. Bioresour. Technol., 2012, 105, 60-66.

22. Mehanna, M. et al., Using microbial desalination cells to reduce water salinity prior to reverse osmosis. Energy Environ. Sci., 2010, 3, 1114-1120.

23. Franks, A. E., Nevin, K. P., Jia, H. F., Izallalen, M., Woodard, T. L. and Lovley, D. R., Novel strategy for three-dimensional realtime imaging of microbial fuel cell communities: Monitoring the inhibitory effects of proton accumulation within the anode biofilm. Energy Environ. Sci., 2009, 2, 113-119.

24. Lee, H. S., Parameswaran, P., Kato-Marcus, A., Torres, C. I. and Rittmann, B. E., Evaluation of energy-conversion efficiencies in microbial fuel cells (MFCs) utilizing fermentable and nonfermentable substrates. Water. Res., 2008, 42(6-7), 15011510 .

25. Mercer, Microbial Fuel Cells: Generating Power from Waste, illumin.usc.edu April (vol. XV (II), Online), 2014, 26.

26. Katuri, K. P., Enright, A., Flaherty, V. O. and Leech, D., Microbial analysis of anodic biofilm in a microbial fuel cell using slaughterhouse wastewater. Bioelectrochem, 2012, 87, 164-171.

27. Kokabian, B. and Gude, V. G., Sustainable photosynthetic biocathode in microbial desalination cells. J. Chem. Eng., 2015, 262, 958-965.

28. Rabaey, K., Clauwaert, P., Aelterman, P. and Verstraete, W., Tubular microbial fuel cells for efficient electricity generation. Environ. Sci. Technol., 2005, 39, 8077-8082.

29. Min, B. and Logan, B. E., Continuous electricity generation from domestic wastewater and organic substrates in a flat plate microbial fuel cell. Environ. Sci. Technol., 2004, 38, 58095814.

30. Sun, J. J., Zhao, H. Z., Yang, Q. Z., Song, J. and Xue, A., A novel layer-by-layer self assembled carbon nanotube-based anode, preparation, characterization, and application in microbial fuel cell. Electrochim. Acta, 2010, 55, 3041-3047.

31. Rabaey, K., Angenent, L., Schroder, U. and Keller, J., Bioelectrochemical Systems: From Extracellular Electron Transfer to Biotechnological Application, IWA Publishing, London, 2009, 1st edn.

32. Aelterman, P., Versichele, M., Marzorati, M., Boon, N. and Verstraete, W., Loading rate and external resistance control the electricity generation of microbial fuel cells with different three-dimensional anodes. Bioresour. Technol., 2008, 99, 88958902

33. Xie, X., Hu, L. B., Pasta, M., Wells, G. F., Kong, D. S., Criddle, C. S. and Cui, Y., Three-dimensional carbon nanotube-textile anode for high-performance microbial fuel cells. Nano. Lett., 2011, 11, 291-296.

ACKNOWLEDGEMENTS. We thank Science \& Engineering Research Board (SERB) Fast Track Young Scientist Award Scheme (Financial order no. SR/FT/LS-14/2011) for funding and the Director, CSIR-NEERI for his support and permission to carry out this work.

Received 30 September 2015; revised accepted 26 May 2016

doi: $10.18520 / \mathrm{cs} / \mathrm{v} 111 / \mathrm{i6} / 1077-1083$

\section{A time-series forecasting-based prediction model to estimate groundwater levels in India}

\author{
Debasish Sena* and Naresh Kumar Nagwani \\ National Institute of Technology, Raipur 492 010, India
}

India is one of the fast developing countries in the world with a growth rate of $6.4 \%$. Rapid industrialization is the main cause behind such growth. Although industrialization is of utmost importance for growth, sustainability of ecology is also a matter of concern. India has a vast coastline, but the saline water is not suitable for industrialization; so groundwater is the primary source for both industrialization and human consumption. Agriculture plays a major role in India's economy and irrigation is also dependent on groundwater to some extent. Hence the study of groundwater levels is the need of the hour. In this study, time-series techniques like fuzzy time-series analysis and ARIMA are utilized for forecasting monthly groundwater levels. Experiments are performed on the datasets collected from different regions of India. The experimental results demonstrate that fuzzy time series analysis yields more accurate forecast of groundwater levels compared to the ARIMA model. The results of this study can be utilized for planning a suitable policy for groundwater use and its proper regulation to avoid future crisis.

Keywords: Fuzzy logic, groundwater level, prediction models, time-series forecasting.

GROUNDWATER is a major resource in our country. In fact, India tops the list of groundwater abstracting countries. Groundwater is essential for sustainability of ecosystem; it provides stream water during drought conditions. Considering the effects of climate change, landuse change and global environmental changes like change in the amount of precipitation, increase in temperature and increase in demand of groundwater because of population growth, it is important to assess them ${ }^{1}$. Water being a dynamic resource, its storage undergoes continuous change either by recharge from various sources or discharge due to extraction or natural basin outflow. Hence periodic monitoring of groundwater levels is imperative for planning systematic development and management of groundwater resources ${ }^{2}$.

Groundwater level prediction in India is of utmost importance as our large population is heavily dependent on groundwater for daily consumption. Also groundwater is heavily used both for irrigation and industrialization in India. Due to faulty irrigation system, a lot of groundwater is wasted. Prediction of groundwater levels is the

*For correspondence. (e-mail: dsena.mtech2013.ee@nitrr.ac.in) 